\title{
NOVI ET AETERNI TESTAMENTI
}

\section{Znamienna paralela}

Dwie odnowy: biblijna i liturgiczna, występują we współczesnym katolicyzmie jako zjawisko równoległe. Oba te ruchy zrodziły się gdzieś w II-ej połowie ubiegłego stulecia i odtąd rozwijają się bez przerwy. Nie zdołała ich powstrzymać ani pierwsza ani druga wojna światowa, nie stłumiły też zaintere;owania nimi u wiernych wielkie kryzysy i przemiany społeczne, jakie przeżywa wiek obecny. Oba te ruchy - jak wszystko, co rodzi się z Ducha Bożego - znalazły w Kościele zrozumienie i poparcie in capite et in membris. I tak Stolica Apostolska w czasach ostatnich odzywa się raz po raz zarówno w sprawie Pisma św. i liturgii, a nierzadko jeden i ten sam papież rzuca w obu sprawach ważkie wypowiedzi. Dość tylko wspomnieć św. Piusa X, założyciela rzymskiego Instytutu Biblijnego, a jednocześnie reformatora brewiarza i propagatora śpiewu kościelnego. A i Pius XII w krótkim odstępie czasu po doniosłej encyklice o rozwoju studiów bilijnych (,Divino aflante Spiritu“") poświęca inną specjalnie sprawie liturgii (,Mediator Dei"). Taką samą paralelę w zainteresowaniach obydwu ruchami dostrzec można i wśród wiernych. Mimo że jeden i drugi ruch zrodziły się $\mathrm{w}$ kołach specjalistów, a więc osób duchownych, bardzo szybko ogarnął szerokie koła katolików świeckich, i to bynajmniej nie samej tylko elity, jak to widać $\mathrm{z}$ akcji, jaką z powodzeniem prowadzi w Austrii O. Pius Parsch. W całym świecie katolickim świadczy o tym wymownie fakt coraz częstszego z jednej strony poruszania tematyki biblijnej w literaturze oraz szybkiego rozchodzenia się współczesnych przekładów Pisma św. na języki nowożytne, z drugiej zaś - gromadne garnięcie się wiernych do liturgii. Przejawem Łego jest chęć wspólnego przeżywania liturgii przez czynne 
w niej uczestniczenie, przez wspólny śpiew gregoriański, co niekiedy przybiera nawet formę jakiegoś oddolnego dopingu stosowanego względem duszpasterzy.

\section{Geneza i sens}

tych równoległych zjawisk warte są głębszego zastanowieniá Bezpośrednie przyczyny historyczne obu tych ruchów tylko w pewnej mierze wyjaśniają ich doniosłość. Bo ani XIX-wieczny rozkwit monastyki benedyktyńskiej na Zachodzie z jednej strony ani z drugiej - intensywny rozwój fi : logii semickiej i archeologii Palestyny, choć niewątpliwie $r$ dzo zaważyły na obu tych ruchach nie wyjaśniają samt o faktu paraleli, jakiegoś wzajemnego powiązania jednej i d giej odnowy. Zbytnio bowiem uproszczona była próba tiłu czenia tego związku faktem, że liturgia stosuje przewa .iie słowa Pisma św. Racji tedy szukać trzebr. głębiej. U pa tor tego równoległego zjawiska można doszukać się chyba : goś głodu, jakiejś dążności do tego, by w dobie dzisiejsz : jak najpełniej przeżywać autentyczne chrześcijaństwo. Tentencjє te najlepiej oddaje termin ,odnowa“, bo idzie w nich nie o jakąś częściową tylko reformę, lecz o pełny nawrót do tego, cc już św. Augustyn nazwał ,miłościa zawsze stara $i$ zar $\varsigma z$ nowa“. Zajmiemy się więc w szkicu niniejszym wieczną aktua! nością Nowego Testamentu, pojętego możliwie jak najszerzej Posłuży nam do tego celu rozważanie podstawowych poję biblijnych Przymierza i Testamentu, określanych jednym ter minem greckim ,DIATHEKE“. A spróbujemy tego d-" ia w duchu odnowy biblijnej i liturgicznej, trzymając w $t \epsilon$ ręce Pismo św., a w drugiej - Mszał, bo to nam pozwo cu cić światło na istotną przyczynę tej równoległości.

\section{Historyczny wielki czwartek a mszal .}

Otwórzmy mszał rzymski na słowach konsekracji i zestaw my je z czterma sprawozdaniami o Wielkim Czwartku zawa: tymi w Nowym Testamencie (Mt 26, 26-28, Mr 14, 22-2 Ek 22, 19n, 1 Kor 11, 23-25). Nad postacią chleba wymaw. 
kapłan dziś słowa te same, które czytamy i w Piśmie św. z dodatkiem mało znaczącego ,enim" — ,bowiem“. Natomiast inaczej jest z drugą postacią. Słów mszału: T en jest b owiem kielich Krwi mojej Nowegoi Wiecznego Przymierza: Tajemnica wiary: który za was i za wielu wylany będzie na odpuszczenie grze¿hów - w takim zestawieniu nie ma w Piśmie św. Sens ogólny tekstów jest wprawdzie ten sam, lecz słowne sformulowanie - zgoła odmienne. Mszał przy tym nie tylko zestawia razem i harmonizuje dane wszystkich tych sprawozdań biblij? ch, ale czyni coś wiẹcej: Dokonuje mianowicie ciekawej syny teologicznej korzystając z całego Pisma św. Eatwo to wyyje następująca analiza, która dotyczy interesujących nas 'w novum et a eternum. Z dwu tych określeń pierwsze : iże się powołać na wszystkie przytoczone wyżej teksty (z wyja tiem greckiego tekstu Markowego). Drugie natomiast nie

- o. tego dckonać Nasuwa się więc zrozumiałe pytanie, czy a e te r n u mie jest czasem jakimś późniejszym dodatkiè , jakaśs glosą dopisaną przez modlący się Kościół tak, jak to $j \in$;t $z$ pełnym sensu następnym określeniem mszału: $m y-$ sterium fidei. Otóż tak nie jest. Bo choć żadne ze sprawozdań przytoczonych nie mówi wyraźnie o wieczności NoW ro Przymierza, niemniej jednak pojęcie to należy do autentycznego skarbca biblijnego. Jest to, co więcej, nawet jedna mówiąc obrazowo - z osi wspólnych, łączących razem księgi obydwu Testamentów. Zacznijmy od Starego.

\section{Przymierze - Krew - Spoleczność}

-- rójca pojęć jawi się wyraźnie w opisie przymierza zawartego między Bogiem a Abrahamem. Nie jest ono wpraw$r$ ie chronologicznie pierwsze na kartach Starego Testamentu, , je wyprzedza przymierze zawarte z Noem (Rodz. 9. 9-17), i le jest najbardziej typowe. Dwakroć je zawiera patriarcha Abraham a zawsze jako protoplasta narodu wybranego (Rodz $15,8-21,17,1-27)$. W obydwu tych opisach Genezy łatwo dojrzeć te wspólne składniki: obustronne zobowiązania Boga i człowieka, przypieczętowanie układu krwią (za pierwszym ra- 
zem - żertwy, za drugim - własną), wreszcie aspekt społeczny - fakt powstania nowej zbiorowości. Umowa ta bowiem dotyczy nie tylko samego protoplasty jako jednostki, lecz i ,nasienia“ jego, które Pan w przyszłości rozmnoży ,jako gwiazdy niebieskie i jako piasek, który jest na brzegu morskim". Co więcej - w Abrahama potomstwie będą „,błogosławione wszystkie narody ziemi".

Otwieramy następną księge - Wyjścia. I oto spostrzegamy, że synaickie przymierze zawiera te same elementy. Przytoczyć warto w całości końcową scenę zawarcia tego paktu: „I napisat Mojżesz wszystkie stowa Pańskie. A rano wstawszy zbudowat ołtarz przy samej górze i 12 słupów według 12 pokoleń Izraєlowych. I postat młodzieńców z synów Izraelowych, $i$ ofiarowali cielce na ofiary zapokojne Panu. Wziat tedy Mojżesz połowe krwi $i$ wlat $w$ czasze, a druga połowe wylat na ottarz. I wziawszy ksiegi przymierza czytat, a lud stuchał, i rzekli: Wszystko, co rzekt Pan, uczynimy i będziemy postuszni. A on wzięta krwia pokropit lud $i$ rzekt: TA JEST KREW PRZYMIERZA, które Pan postanowił $z$ wami na wszystkie te stowa" (Wyjść 24, 4-8). W przymierzu tym Jahwe przez krew konsekruje dla siebie Izraela na wyłączną własność. Jest to dopiero tylko ,cień dóbr przyszłych“ (Żyd. 10, 1), bo

\section{Nastąi nowe przymierze}

jak zgodnie wieszczą wielcy prorocy Izraela: Izajasz, Jeremiasz i Ezechiel. Tragedią ich - po ludzku mówiąc - było to, że musieli patrzeć, jak lud odstępców łamie przymierze, że musieli mu za to grozic karami, a w zamian za takie poselstwo cierpieć prześladowanie. Tym zaś, co ich mimo to napełniało radością, była ukazana im wizja Nowego Przymierza - Nowego i Wiecznego już tym razem.

Raz grożący, innym razem pocieszający Izajasz zapewnia, że już „przymierze pokoju nie zachwieje się" (Iz 54, 10), bo Jahwe uczyni ,przymierze wieczne" $(55,3)$, które na tym będzie polegać, iż „słowa, które Bóg złożył w ustach proroka, nie odstapia od ust jego $i$ od ust nasienia jego... a $\dot{z}$ na wieki “ $(59,21)$.. 
Nowe i doskonalsze, bo wewnetrzne i duchowe przymierze, zapisane na tablicach serc giosi Jeremiasz: „Zaprawdę... przymierze nowe, nie wedtug przymierza, którem z ojcami ich zawart... położę zakon mój we wnętrznościach i na sercu ich napisze go, i będe im Bogiem, a oni będa mi ludem" (Jer 31, $31-33)$.

Do tego obrazu nowe rysy dorzuci prorok wygnańców Ezechiel. Przed oczyma ich stęskionymi za prawdziwym kultem Jedynego roztoczy on wizję Nowego Przymierza i ukaże im znak Swiątyni: ,I uczynię z nimi przymierze pokoju, przymierze wieczne będzie im, i ugruntuje ich $i$ rozmnoże, $i$ dam światynie moja w środku ich na wieki. I będzie przybytek mój między nimi, i będe im Bogiem, a oni będa mi ludem..." (Ez 37, 26n).

Zbierając w jedno te głosy, słyszymy zapowiedź Nowego i Wiecznego Przymierza. Będzie ono przedłużeniem i dopełnieniem ostatecznym tego wszystkiego, co w zarysie ukazywało sie pierwsze. Każdy element pierwszego ulegnie sublimacji, uduchowieniu w Nowym i Wiecznym Przymierzu. Bedzie zatem pakt obustronny, będzie krew ofiary pieczętująca go, będzie trwały i serdeczny związek Boga z ludem Jego - nowym Izraelem.

\section{Potwierdzenie realizacji}

tych wypowiedzi dokonuje się właśnie w Wielki Czwartek, i to $w$ ofierze eucharystycznej w wieczerniku antycypujacej krzyż Wielkiego Piątku. ,Kapłan na wieki wedııg obrzadku Melchizedeka" (Ps 109, 4) - Jezus Chrystus właśnie nad chlebem i winem wypowiada słowa konsekracji, które głosza uroczyście ziszczenie się typów i zapowiedzi mówiących obrazem czy słowem o Nowym i Wiecznym Przymierzu. Oto punkt dziejowy, w którym spotykaja sie typ i antytyp - zapowiedź i wypełrienie.

Przymierze to jest istotne Now e. Zastąpiło bowiem Stare - „wypełniając je“: 
Novum Pascha novae legis

Phase vetus terminant -

trafnie o Wielkim Czwartku śpiewa liturgia, posługując się słowami Tomaszowymi w „Lauda Sion“. Krew, która pieczętuje i. scala nowe to przymierze jest krwią Ofiary jedynego Pośrednika, krwią przelaną $w$ darze miłosnym dla Ojca $w$ imieniu wszystkich braci. A celem tej ofiary - przeobrazić ludzi, i to każdego z nich, w prawdziwe dzieci Boże, wołaiace w Duchu: „Abba, Ojcze!“", a wszystkich razem przeobrazić w nowego Izraela, obywateli „górnego, wolnego Jeruzalem“ (Gal 4, 26).

Nowe to przymierze jest również wi e c zne. Ta cecha wieczności każe nam nie w ludziach lecz wyłącznie w Bogu, szukać swego sprawcy i poręczyciela. Jedynie łaska tego dokona, że nowe to przymierze mimo słabości i niewierności ludzkiego kontrahenta będzie miało zapewnioną moc wiecznotrwała. Przymierze to jest wieczne, bo jest ostateczne i innego już nie będzie, skoro obejmie wszystkie zapowiedziane dobra. Jest ono wieczne jako obowiązujące na zawsze. Jest ono wieczne, bo zasadza się już nie tylko na ,literze“, lecz będzie miało swe giówne oparcie „w duchu $i$ prawdzie“. Jest ono wieczne, bo wraz z Królestwem Bożym, które, w nas jest", zawsze bçdzic rosnać i obfitować w owoce trwałe. Jest ono wieczne, bo pieczętująca je Krew Baranka eucharystycznego wciąż się na nowo i bez przerwy przelewa na oltarzach „od wschodu stońca aż do zachodu“. Jest ona wieczna, bo się nigdy nie skończy: tu rozpoczęte przejdzie $\mathrm{w}$,,żywot wieku przyszłego".

I coś więcej jeszcze można odczytać ze słów konsekracji wina branych według brzmienia katechezy Pawłowej (1 Kor 11, 25; Łk 22, 30). Widać mianowicie, że Chrystus jest nie tylko „Pośrednikiem Nowego Przymierza“ (Żyd. 9, 15), ale sam po prostu jest Nowym Przymierzem, skoro mówi: ,Ten kielich jest Nowym Przymierzem we Krwi mojej“. On sam jest Przymierzem, podobnie jak On sam jest Królestwem Bożym, które w nas jest ${ }^{1}$ ). Nowe i Wieczne Przymierze to Jezus Chrystus.

1) Por. J. Bonsirven, Théologie du N. T., Paris 1951, 103. 


\section{A dlaczego testament?}

Uważnie porównując dalej tekst konsekracji drugiej postaci z mszału z tekstem omawianych sprawozdań biblijnych, zauważymy nową różnicę. Oto łacina mszalna, za Wulgatą idąc, ma słowo TESTAMENTUM, my zaś dotąd mówiliśmy o Przymierzu. Przymierze więc czy Testament? Które z pojęć jest biblijne? I jedno i drugie, bo - jak wyżej wspomnieliśmy określa je obydwa ten sam termin grecki diatheke. Przymierze i Testament - zasadniczo dwa różne typy kontaktu tworzą w teologii biblijnej pełen treści amalgamat. Już w tekstach Starego Testamentu tłumaczenie Wulgaty stawia obok siebie ,arkę Przymierza“ i ,arke Testamentu“. Ale najwięcej ma nam do powiedzenia Wielki Czwartek. Nastrój Wieczernika nasuwa istotnie myśl o ostatniej woli. Jesteśmy tam świadkami pożegnania przed śmiercią, słyszymy ostatnie zalecenia, a obrzęd eucharystyczny kończy się rozkazem: „To czyńcie na moja pamiątkę". W chwilę później - według opisu Łukaszowego - Pan mówi do apostołów: „Ja wam przekazuję Królestwo, jako mi przekazał Ojciec mój“ (Łk 22, 29). Użyte w tym miejscu słowo ,przekazać“ ma po grecku ten sam źródłosłów, co i d i a th e k e - testament. Mówi zatem Chrystus o testamentarnym przekazaniu Swej woli i Swego połannictwa. Najgłębsze atoli ujęcie i biblijne uzasadnienie tego połączenia pojęć przymierza i testamentu znajdziemy w liście do Żydów. Apostoł przeprowadzając tam dłuższy wywód porównawczy między Starym i Nowym Testamentem podkreśla w sposób szczególny Nowe i wieczne kapłaństwo Jezusa Chrystusa, które zna tylko jedną jedyną Ofiarę. Dla naszego tematu najciekawsze są wiersze 15-18 rozdziału 9-tego, gdzie termin di a the ke w jednym tekście trzeba tłumaczyć najpierw jako „przymierze“ (w. 15), tuż zaraz obok w wierszu następnym jako ,testament“: I ten tekst w całości warto przytoczyć. „Dlatego jest (Jezus Chrystus) pośrednikiem nowego przymierza, żeby przez śmierć poniesiona na odkupienie przestępstw popetnionych za przymierza pierwszego, wezwani posiedli obiecane im dziedzictwo wieczne. Bo gdzie jest testament, tam musi nastapić śmierć tego, który go czyni. Testament bowiem nabiera 
mocy z chwila śmierci, inaczej nie ma znaczenia dopóki ̇̇yje ten, kto testament uczynit. Dlatego i pierwszy nie bez krwi. ustanowiony byz" (Źyd. 9, 15-18). I tu autor święty przytacza wyżej już omówioną scenę z Mojżeszem zapisaną w Księdze Wyjścia $(24,8)$. To przejście od jednego pojęcia do drugiego łatwiej można zrozumieć, gdy się zważy, jak chętnie Pismo św. posługuje się wyrazem „dziedzictwo“, ściśle związanym z pojęciem testamentu, na określenie zespołu dóbr, jakie Bóg daje ludzkości. A szczególnie dobitnie w teologii św. Pawła terminy „dziedzic" czy ,wspótdziedzic" podkreślają obustronną solidarność, jaką ustanowił między Bogiem a rodzajem ludzkim fakt Wcielenia i Odkupienia. Tak więc Przymierze i Testament są dwoma nierozdzielnymi aspektami jednej i tej samej rzeczywistości.

\section{Od faktu do księgi}

przebiega dalsza wędrówka semantyczna "testament". Taki kontrakt jest pzymierze czy testament w ludzkich stosunkach domaga się do swej ważności spisania go w postaci jakiegoś dokumentu.

Prawnik Tertulian użyje więc z czasem terminu technicznego ,instrumentum“. Nic więc dziwnego, że i nazwa z czasem przesunęła się z samego faktu (historyczngo zarazem i nadprzyrodzonego) Przymierza-Testamentu na księgi głoszące o nim i o jego następstwach czy wymaganiach. I to rozszerzenie znaczeniowe spotykamy na kartach Pisma św. Pouczający jest $w$ tej mierze 3 rozdział 2 listu do Koryntian. Sw. Paweł nazywa tam Apostołów ,stugami Nowego Przymierza, nie wedtug litery, ale według ducha..." (w. 6), czyniąc tu aluzję do. wyrycia dekalogu na kamieniu, a nieco dalej zarzuci synom Izraela, że ,aż po dzień dzisiejszy... zasłona przy czytaniu Starego Testamentu... spoczywa na sercu ich" (w. 15n). Tak więc „N ow y Testament" staje się terminem technicznym na oznaczenie $27 \mathrm{ksiagg,} \mathrm{które} \mathrm{można} \mathrm{dziś} \mathrm{wydać} \mathrm{w} \mathrm{formacie} \mathrm{nie-}$ wielkiej książki. Wędrówka znaczeniowa terminu nie uprawnia jednak do zacieśnienia zakresu ni do zubożania treści samego pojęcia. Jako wyraz pewnego protestu przeciw takim próbom ciasnego ujmowania terminu „Nowy Testament" przy- 
toczyć można nastẹpujące słowa Papiniego o ewangelii: ,Kto czyta Ewangelie, nie czyta księgi... Ewangelia znajduje sie ponad wszelka klasyfikacja literacka. Nie jest księga, ale cudem - jest mianowicie pośmiertnym wcieleniem, Tego, który każdego z nas ukochat więcej, niż sami siebie kochać jesteśmy $z$ dolni" ${ }^{1}$ ). Nie co innego też sugeruje 1 e x o r a n d i - liturgia, gdy podczas mszy uroczystej każe akolitom stawać ze światłem. po obydwu stronach ewangeliarza, okadzanego wówczas przez. diakona tak, jak się okadza Najświętszy Sakrament. Bo „Nowy Testament" jako księga to jedna $\mathrm{z}$ form obecności wśród nas Boga-Człowieka.

Dotychczasowe rozważania zarysowują już nam

\section{pełną koncepcję Nowego Testamentu}

taką, która leży u źródeł odnowy biblijnej. Niepozbawione dozy słuszności i swoistego uroku są wstępne refleksje na temat Nowego Testamentu, jakie snuł D. Mereżkowski w swoim ,Jezusie Nieznanym": ,Tak jak ja, człowiek - rozczytała się w niej (tj. w księdze NT) ludzkość, i może tak samo rzeknie jak ja: „Co wezme ze soba do grobu? Ja. Z czym wstane z grobu? $Z$ nia. Co robiłem na ziemi? Czytałem ja.". To przeraźliwie dużo dla człowieka, a może i dla całej ludzkości, ale dla tej Księgiprzeraźliwie mało... Nie można przeczytać Ewangelii nie czyniac tego, co ona głosi. A kto $z$ nas czyni to? Dlatego właśnie jest to najmniej czytane z ksiag, najbardziej nieznane. Swiat taki, jaki jest, i ta księga nie moga wespót istnieć. On albo ona... Zginać musi albo ta Księga, albo ten swiat" ${ }^{1}$ ). Mimo całego piękna wszakże ze słów tych wieje pesymizm. Takiego pesymizmu nie może podzielać współczesny katolik, zwłaszcza żyjacy duchem odnowy biblijnej i liturgicznej. Po prostu dlatego, że ma inną zgoła koncepcję Nowego Testamentu. Nowy Testament dla niego to nie tylko księga, którą - według słów. Mereżkowskiego - „swiat połknat, jak zdrowy łyka trucizne

1) Por. G. Papini, Gli operai della vigna, Firenze 1929 s. 61.

1) Por. D. Mereżkowski, Jezus Nieznany, Warszawa, s. 61.

2) Por. d. c., s. 62 .

3) Por. Tyg. Powsz. nr 32 (385) z dn. 10. VIII. 1952, s. 1. 
a chory lekarstwo i.walczy $z$ nia ${ }^{\prime 2}$ ), lecz Boża na świecie rzeczywistość - zawsze nowa i wieczyście aktualna. Tę właściwą koncepcję i postawę wobec Nowego Testamentu trafnie scharakteryzował O. Jean Daniélou T. J. w tych słowach: "Nowy Testament trwa dalej pośród nas w sakramentach Kościoła. Chrześcijanin jest świadom, i̇e żyje pośród trwajacej nadal histori świ ̨ te $j$, że żyje $w$ świecie, w którym Bóg nie przestaje działać, interweniować, dokonywać swych dziet wspaniałych... Oto historia prawdziwa, w niej bowiem w sposób tajemniczy przez działanie miłości nadprzyrodzonej wypracowuje sie niezniszczalne Ciało Chrystusa" ${ }^{3}$ ). Bo zarówno najgłębsza treść Nowego Testamentu jako księgi jak i Nowe Przymierze w przelewanej wciąż na oltarzach Krwi Baranka - to nic innego, jeno - według słów Apostoła — „Jezus Chrystus wczoraj i dziś - tenże sam i na wieki" (Żyd. 13, 8).

\section{Dwie odnowy - jedna sprawa}

Mówi się dziś chętnie w życiu religijnym o jakimś ,grand retour". Takim właśnie powrotem do żywego Chrystusa jest i ta dwojaka odnowa. Dokonuje się ona wśród wiernych w poczuciu wiecznej aktualności Nowego Przymierza, które nadal trwa i obowiązuje.

Katolik dzisiejszy w niemniejszym stopniu niż praojciec jego w wierze sprzed wieków 19-tu może i powinien się czuć osobiście odpowiedzialnym i niezastąpionym czynnikiem, który urzeczywistnia na swym odcinku życiowym postępy Przymierza, warunki Testamentu i granice Królestwa Bożego. Zanim to dotarło do jego świadomości - po większej części - już stał się przez chrzest ,współdziedzicem Chrystusa". Zanim samodzielnie otworzył karty Nowego Testamentu jako Księgi, już do niego przynależał jako do historycznej a nadprzyrodzonej rzeczywistości. Zawdzięcza to wszystko Kościołowi. Liturgia bowiem Kościoła stawia wiernego wobec nadprzyrodzonej rzeczywistości ukrytej pod osłoną m y s teri u m fidei, a urząd nauczycielski tegoż Kościoła poucza go o niej, w dobie ostatniej zalecając szczególnie wprost czytanie ksiąg świętych. I taki porządek rzeczy jest tutaj istotny. Tak było przecież ongiś: za- 
nim pierwsza litera „Nowego Testamentu“ została skreślona trzciną na papirusie w roku 51 naszej ery, już na lat kilkanaście przedtem, właśnie od pierwszej mszy Wielkiego Czwartku, istnieć poczęło Nowe Przymierze i Testament we Krwi Jezusa Chrystusa. Mszał więc i Nowy Testament w ręku współczesnego katolika dopełniają się wzajemnie i pozwalają mu w pełni przeżywać i współtworzyć Testament Nowy i Wieczny.

Tyniec

O. AUGUSTYN JANKOWSKI OSB.

\section{SZKIC HISTORYCZNY PRZEKLADÓW PSAETERZA DO WIEKU XIX}

Psałterz przynieśli prawdopodobnie wraz z chrześcijaństwem do Polski duchowni czescy, którzy przybyli z Dąbrówką. Głosili oni nauki w języku czeskim, który wówczas bardzo mało różnił się od języka polskiego. Do wieku XV, różnica mię dzy tymi językami była w przybliżeniu taka, jak dzisiaj między gwarami regionalnymi. Chociaż nie posiadamy dokumentów i świadectw, możemy z dużym prawdopodobieństwem przypuszczać, że pierwsze teksty Pisma św. na terenie Polski były w języku czeskim. Czesi pierwsi posiadają własny przekład Pisma św. Z wieku X. pochodzi kilka rozdziałów ewangelii św. Jana, znalezionych w Zgorzelcu w 1928 r. Szerzyło się to tłumaczenie szczególnie pod wpływem obrządku greckiego, zaszczepionego tam przez św. Cyryla i jego uczniów. W Polsce zaś pierwsze perykopy Pisma św. wyjęte są z Wulgaty, bo tu od samego początku istnieje obrządek łaciński.

\section{Psałterz Kingi}

Już w wieku XIII. zjawia się potrzeba modlitewnika w języku polskim. Z tego też czasu pochodzi pierwszy polski rękopis psałterza, z którego modliła się św. Kinga ${ }^{1}$ ). Miała zwyczaj przed każdym opuszczeniem kościoła odmówić dziesięć psalmów, ,in vulgari“" Rękopis ten jednak zaginął. Był on źródłem,

1) Por Vita S. Cunegundis, Archiw für slav. Phil. 7, s. $64 \overline{5}$. 